\section{Journal of Global \\ Education Sciences}

Vol. 3, $\mathrm{N}^{\circ} 1,2021$
A publication of

CINCADER

Centre of Research and Training for

Regional Development

Online at www.journals.cincader.org

\title{
Effect of the protection measures established by the peruvian government to prevent the Coronavirus in the Barranca district during the second wave of infections
} [Efecto de las medidas de protección establecidas por el gobierno peruano para prevenir el Coronavirus en el distrito de Barranca durante la segunda ola de contagios]

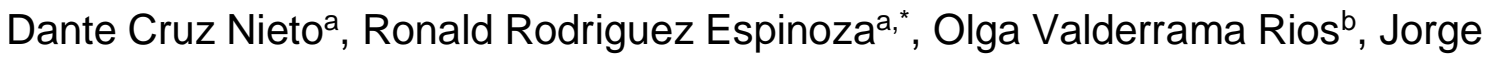
López Balarezo ${ }^{a}$, Ronald Ramos Pacheco ${ }^{a}$, Elvira Castañeda Chirre ${ }^{a}$, José Yovera Saldarriagac ${ }^{c}$, Patricia Meyhuey Pala ${ }^{d}$

\author{
aUniversidad Nacional José Faustino Sánchez Carrión, Huacho, Perú \\ bUniversidad Nacional del Callao, Perú \\ 'Universidad Nacional Santiago Antúnez de Mayolo, Huaraz, Perú \\ ¿Universidad Nacional de Barranca, Perú \\ * rrodriguez@unjfsc.edu.pe
}

Received: 11 January 2021; Accepted: 17 February 2021; Published: 23 February 2021

\section{Resumen}

El objetivo de la investigación es establecer el efecto que tienen las medidas de protección establecidas por el gobierno para reducir el contagio por Covid -19 en el distrito de Barranca durante la segunda ola de contagios. Se recopilaron datos sobre el cumplimento de medidas de protección tales como distanciamiento, uso de mascarillas, de viseras y desinfección con alcohol en lugares públicos cómo calles, mercados, bancos y parques. Para esto, se emplearon instrumentos de toma de datos basados en la inspección visual para constatar el uso adecuado de las medidas de protección, así como una encuesta referida al uso de alcohol como desinfectante; y la data obtenida fue procesada mediante estadísticas básicas y correlación con los datos reportados por el Ministerio de Salud de contagios positivos por Covid-19. Se determinó que existe una relación de crecimiento entre el acatamiento de las medidas de protección y el número de contagios positivos, con coeficientes de correlación para el distanciamiento de 0.7458 , uso de mascarillas de 0.6710 , viseras 0.8784 y empleo de alcohol como desinfectante de 0.7310 . Respecto al análisis de varianza, se obtiene que el uso de viseras influye en el número de contagios positivos, por lo que se concluye que mantener el distanciamiento, además del uso de mascarillas y de alcohol desinfectante son medidas eficaces para controlar el número de contagios por coronavirus.

Palabras clave: Covid-19; medidas de protección; distanciamiento; mascarillas; viseras; alcohol desinfectante 


\section{Journal of Global Education Sciences}

Vol. 3, $\mathbf{N}^{\circ}$ 1, 2021

The objective of the investigation is to establish the effect of the protection measures established by the government to reduce the contagion by Covid -19 in the district of Barranca during the second wave of infections. Data were collected on compliance with protection measures such as distancing, use of masks, visors and disinfection with alcohol in public places such as streets, markets, banks and parks. For this, data collection instruments based on visual inspection were used to verify the appropriate use of protection measures, as well as a survey regarding the use of alcohol as a disinfectant; and the data obtained was processed through basic statistics and correlation with the data reported by the Ministry of Health of positive infections by Covid-19. It was determined that there is a growth relationship between compliance with protection measures and the number of positive infections, with correlation coefficients for distance of 0.7458 , use of 0.6710 masks, 0.8784 visors and use of alcohol as a disinfectant of 0.7310 . Regarding the analysis of variance, it is obtained that the use of visors influences the number of positive infections, which is why it is concluded that maintaining distance, in addition to the use of masks and disinfectant alcohol are effective measures to control the number of infections per coronavirus

Keywords: Covid-19; protection measures; distancing; masks; visors; disinfectant alcohol.

\section{Introduction}

At the end of 2020, the contagion of Covid -19 has increased significantly, which has affected a large percentage of the elderly and those with chronic diseases and who in many cases have been hospitalized. This situation is due to the fact that the protection measures against the disease in public places such as markets, banks, parks and others have not been adequately complied with, causing a new outbreak of the virus.

COVID-19 and the Severe Acute Respiratory Syndrome or SARS-CoV-2 due to the new coronavirus is causing a pandemic with high mortality. Although there are still unknowns to be defined as a new viral infectious disease, advances have been made in the knowledge in relation to clinical behavior and pathogenesis (Serra, 2020).

Likewise, the contagion can be directly by coughing, sneezing and exhaling, by means of which we expel the Flügge droplets that, when suspended in the air, form tiny aerosols, that is, much smaller than the fiber of a hair, and are contagious Well, they have retained the virus. Another way of being infected is indirectly by handling bags, containers and other materials exposed in public places, after which when touching the face there is a probability of being infected. The WHO (World Health Organization) states that airborne transmission occurs when there is a presence of microbes within the nuclei of Flügge droplets, which can remain in the air for long periods of time and spread over distances. greater than one meter, which is known as suspended particles or aerosols. Its nature can predispose the transmission of SARS-CoV-2, hence the importance of knowing the characteristics of the risk of transmission and recommending prevention and control measures in order to block the probability of becoming infected (Mendoza and Mendoza, 2020).

The WHO has warned that countries like Iraq are facing a second wave of coronavirus infections, due to a lack of commitment from their citizens in the implementation of rules such as social distancing, as well as the celebration of special events and increased activity in markets (Dawood \& Dawood, 2021).

Faced with this situation, the government opted for the strict application of protection and confinement measures on a mandatory basis to prevent the virus from spreading; However, these 


\section{Journal of Global Education Sciences}

Vol. 3, $\mathbf{N}^{\circ}$ 1, 2021

measures have reduced the contagion of Covid - 19 but have affected the country's economy, and resulted in the increase in unemployment and informal jobs that is increasingly noticeable in all the cities of the country, in addition to fear in catch. Regarding the actions established to prevent infections, Sedano-Chiroque et al. (2020), describe the main primary prevention measures for COVID-19 in Spain, and consider epidemiological aspects and recommendations applied and reported in other countries, such as the prevention of traveling patients, the importance of hand hygiene, prevention by airway, policies in educational centers and prevention for health personnel.

Within this order of ideas, the great impact that the virus has had during these last months of 2020 stands out, which has affected the elderly, chronically ill and economic instability; giving way to the informal increase and with it the spread of the virus. These events occurred at the end of September and became more acute at the end of the year, which as a consequence produced the second wave of Covid-19. This situation has been a trigger to effectively force the strict and mandatory use to establish protection measures to reduce infections. In this regard, Cabezas (2020), states that the challenges to face this pandemic are short and long-term and that we must currently prepare for a possible second wave. Thus, López and Rodó (2020), according to their results, suggests that the blockages must remain in place for at least 60 days to prevent epidemic growth, as well as a potentially larger second wave of SARS-CoV-2 cases. that happens in a few months. In the province and district of Barranca, protection and prevention measures were not efficiently followed, since the increase in informal employment was significant and with it the probability of being infected. For this reason, it is important to comply with the provisions in order to reduce the contagion of Covid-19 and at the same time articulate, schedule and monitor the influx of people to places such as markets, banks and parks.

\section{Materials and Methods}

\section{Population}

It is made up of the inhabitants of the Barranca district with 71,383 inhabitants (INEI, 2017), being the district with the largest number of population with respect to the other districts of the province.

\section{Sample}

A sample of 100 people per month was taken to carry out the respective evaluations.

\section{Statistical analysis}

The analysis of the determination and correlation coefficients was determined, as well as The analysis of variance (ANOVA) to compare multiple means, in order to determine how protection measures influence the contagion of Covid-19.

\section{Procedure}

- A visual inspection was made to 100 participants per month on the proper use of the protection measures indicated by the government such as maintaining distance, use of masks and visors; those who were surveyed regarding whether they use alcohol as a disinfectant after interacting with objects and people. This was done in public places such as: streets, banks, markets, and parks.

- Data was collected per month from September 2020 to January 2021 on those infected by Covid -19, provided by the Ministry of Health (2021): "DataSet of Deaths and infected by COVID-19".

- A correlation was made on compliance with the control measures with the number of infected by Covid-19, in order to specify how it influenced.

- Finally, it was determined whether through the analysis of variance there was an effect of the protection measures to prevent the spread of Covid-19. 


\section{Journal of Global Education Sciences}

Vol. 3, $\mathbf{N}^{\circ}$ 1, 2021

\section{Results}

\section{Percentage of compliance with protection measures by place}

The results obtained through questionnaires for each month, determined that the percentage of compliance with biosafety regulations decreased at the end of 2020 and January 2021, where the lowest values were observed in January; so much so that in the streets only $26 \%$ adopted the established control measures, in markets with $48 \%$, banks with $73 \%$ and parks with $26 \%$ (See table 1).

Table 1: Percentage of compliance with protection measures by place

\begin{tabular}{lccccc}
\hline Places & September & October & November & December & January \\
\hline Streets & 43 & 35 & 29 & 28 & 26 \\
Markets & 58 & 54 & 51 & 50 & 48 \\
Banks & 76 & 75 & 75 & 75 & 73 \\
Parks & 43 & 35 & 31 & 28 & 26 \\
\hline
\end{tabular}

This result is due to the Christmas holidays, the informal labor increase, the disorder and the crowding that has increased the contagion of Covid-19. Therefore, it is important to maintain order, social distancing and schedule departure times in order to prevent the spread of the virus. In this regard, Llerena \& Sánchez (2020) argue that the emergency generated by the Covid-19 pandemic shows deficiencies in the management of public health services, so the Ministry of Health must articulate with the different organizations that make up health services in Peru, the articulation of research and development of technologies, our labor legislation and the productive sector of the country and its precariousness.

\section{Percentage of compliance with protection measures}

Table 2 shows the results of compliance with the protection measures per month in the district of Barranca. Where it is appreciated again that in January there were the lowest values; the distance decreases to $23 \%$, the use of a mask with $89 \%$, the use of visors in $1 \%$ and alcohol with $51 \%$, so it could be said that at Christmas parties and the beginning of the year there was a relaxation in the use of protection measures.

Table 2: Percentage of compliance with protection measures per month

\begin{tabular}{lccccc}
\hline Protection measures & September & October & November & December & January \\
\hline Distancing & 48 & 37 & 27 & 25 & 23 \\
Face mask & 96 & 94 & 92 & 90 & 89 \\
Visors & 5 & 2 & 1 & 1 & 1 \\
Alcohol & 67 & 61 & 56 & 55 & 51 \\
\hline
\end{tabular}

This relaxation in the use of protection measures may be due to customs and habits related to the Christmas holidays, labor informality, crowding that drastically influenced the reduction of strict compliance with protection measures, being a trigger for the increase of infected and deceased, since contagion is directly or indirectly; According to Cabezas, C. (2020), we must incorporate the unrestricted use of masks, physical distancing and hand hygiene into our life practices; In addition, the health system must strengthen the surveillance of new cases, contact monitoring and isolation, bearing in mind that these measures must be accompanied by provisions aimed at social protection.

\section{Positive and deceased by Covid-19}

Table 3 shows the results given by the Ministry of Health (2021), for positive infections and deaths from Covid-19; showing that in September there were 260 positives and 9 deaths, and after a 
Vol. 3, $\mathbf{N}^{\circ}$ 1, 2021

\section{Journal of Global \\ Education Sciences}

Copyright (C) 2021, CINCADER.

ISSN 2663-3787

DOI: https://doi.org/10.32829/ges.v3i1.215
A publication of

CINCADER

Centre of Research and Training for

Regional Development

Online at www.journals.cincader.org

slight decrease they increased until there were 144 positives and 10 deaths in January. This result is due to the influence of the Christmas holidays, labor informality and crowding.

Table 3: Data of positives and deaths from Covid-19, in the district and province of Barranca

\begin{tabular}{cccccc}
\hline \multirow{2}{*}{ Patients } & \multicolumn{5}{c}{$\mathbf{2 0 2 0}$} \\
\cline { 2 - 6 } & September & October & November & December & January \\
\hline Positives & 260 & 131 & 171 & 151 & 144 \\
Deceased & 9 & 5 & 3 & 7 & 10 \\
\hline
\end{tabular}

Source: Ministry of Health (2021), "DataSet of Deaths and infected by COVID-19"

Influence of protection measures in relation to the number of positive infections and deaths

Regarding compliance with the protection measures with the number of positive infections and deaths, it is observed in figure 1, that in September the highest number was obtained with 260 infected and 9 deaths and the highest percentage of compliance with biosafety regulations; However, in recent months and at the beginning of 2021, the number of infected people is increasing to 143 and deaths to 10 ; This is due to the influence of the Christmas holidays and the informal increase in work.

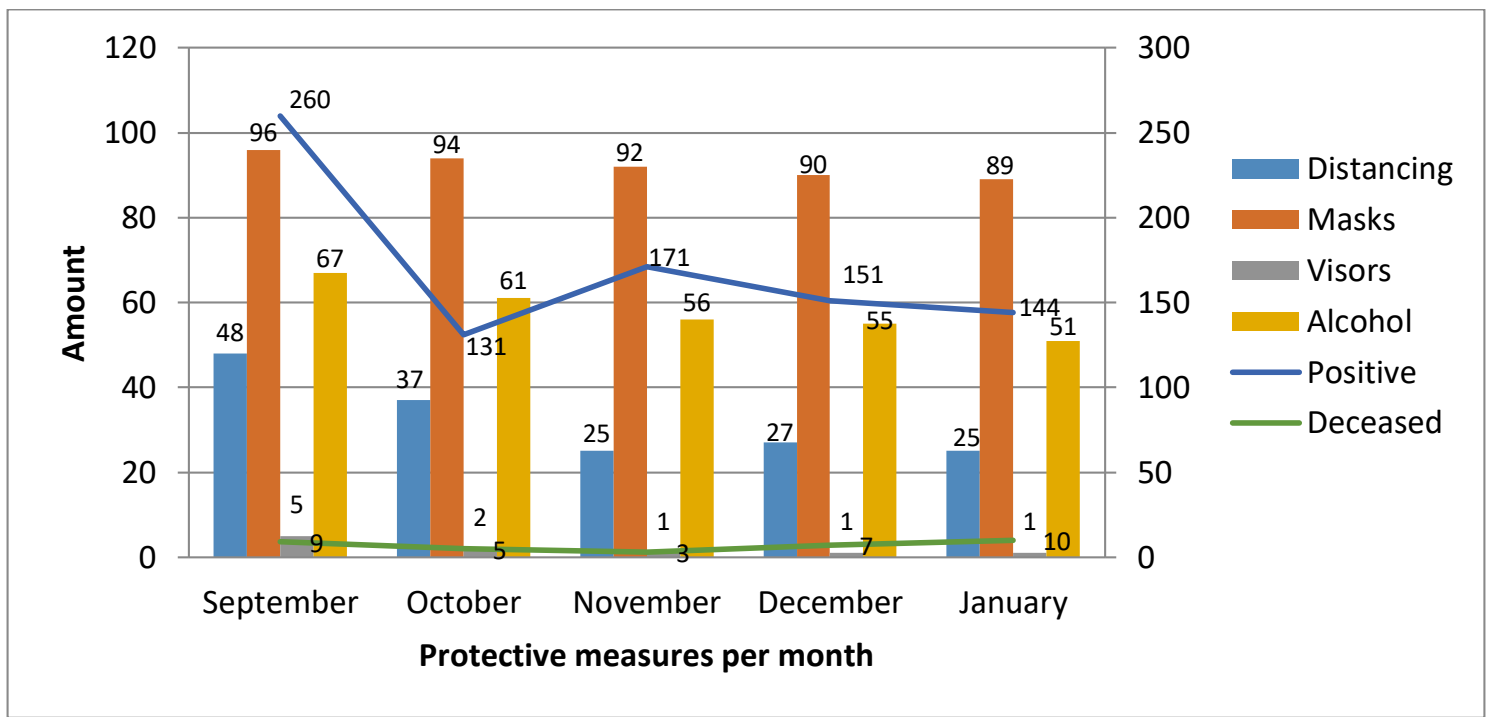

Figure 1: Influence of protection measures in relation to the number of positives and deaths

Influence of the use of protection measures in public places in relation to the number of positive infections and deaths from Covid-19

Figure 2 shows the use of protection measures in public places and their relationship with the positive and deceased. It can be seen that in banks, markets, streets and parks, compliance with the protection regulations significantly decreased in the months of December 2020 and January 2021. This decrease is due to the Christmas holidays, the beginning of the year and informal employment. Although there was a relaxation in the use of the measures, there was no considerable increase in the number of infected, but there was an increase in deaths. This lack in the use of protection measures, leads to an increase in the number of infections, for which 


\section{Journal of Global Education Sciences}

Vol. 3, $\mathbf{N}^{\circ}$ 1, 2021
A publication of

CINCADER

Centre of Research and Training for

Regional Development

Online at www.journals.cincader.org

Copyright (c) 2021, CINCADER.

ISSN 2663-3787

DOI: https://doi.org/10.32829/ges.v3i1.215

Sedano-Chiroque et al. (2020), considers the importance of hand hygiene and respiratory prevention.

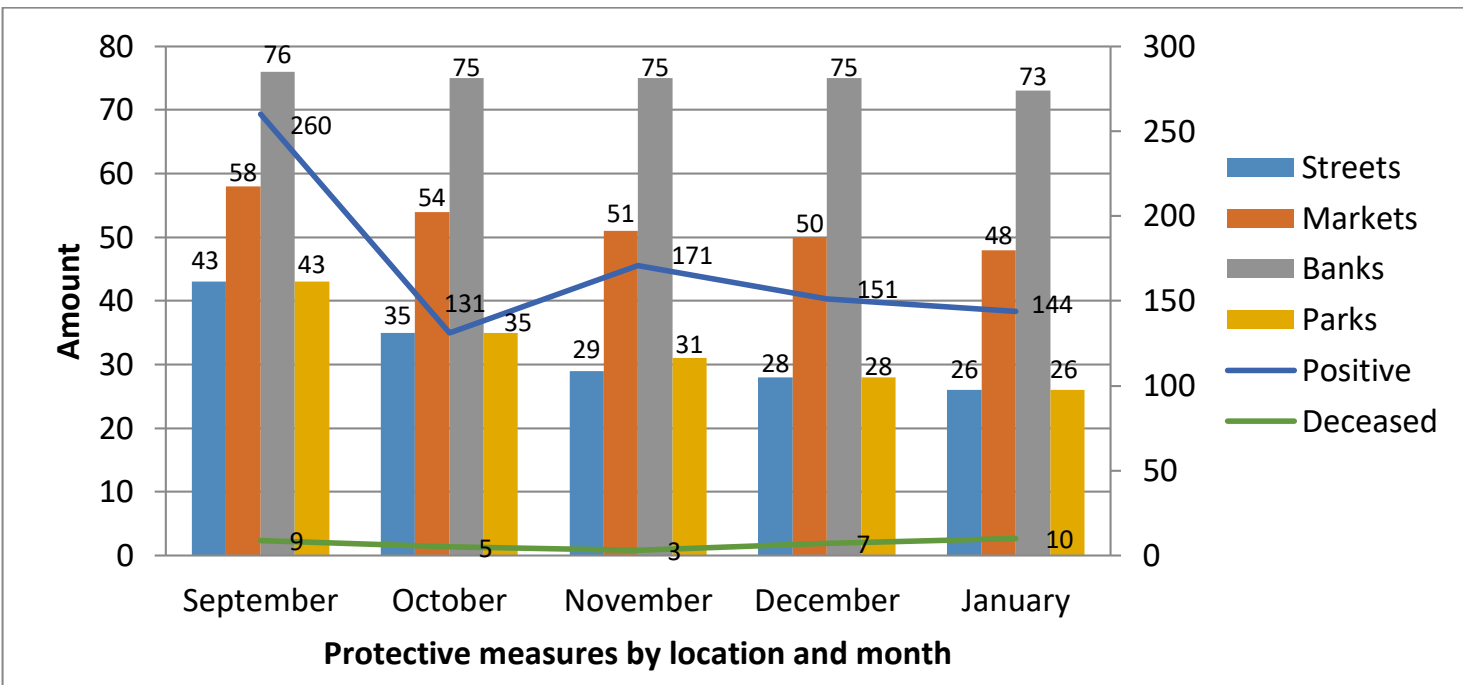

Figure 2: Influence of protection measures in public places in relation to the number of positives and deaths

\section{Correlation of compliance with protection measures with the number of infected}

The results obtained from the correlation between the protection measures with those infected by covid- 19 are detailed in figure $3,4,5$ and 6 , from which it is established that distancing, use of a mask and use of alcohol are within a moderate margin, with a correlation coefficient of 0.7458 , 0.6710 and 0.7310 respectively; In other words, they adequately influence the prevention of infections; while in the use of visors, the correlation is high with 0.8784 , which indicates that it is slightly related to the number of infections. These results are supported by what was stated by Laguna (2014), who states that the interpretation of the correlation coefficient depends on the particular context of application; In general terms, it is considered that a correlation is low below 0.30 in absolute value, that there is a moderate association between 0.30 and 0.70 , and high above 0.70; Therefore, the use of the established protection measures can be considered efficient.

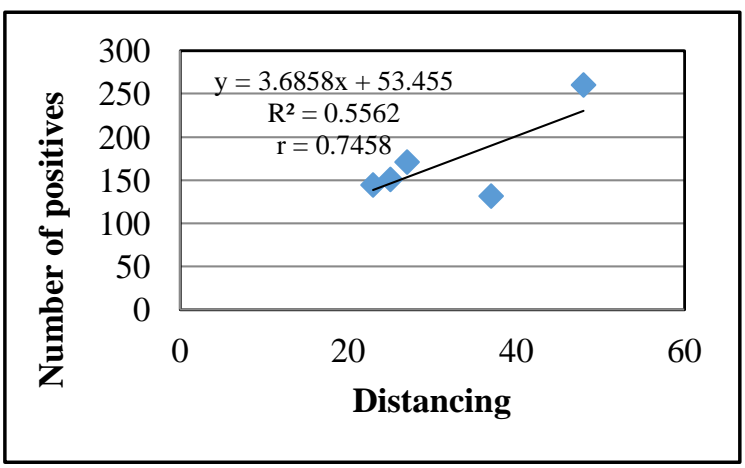

Figure 3: Correlation of distancing with the number of infected by Covid-19

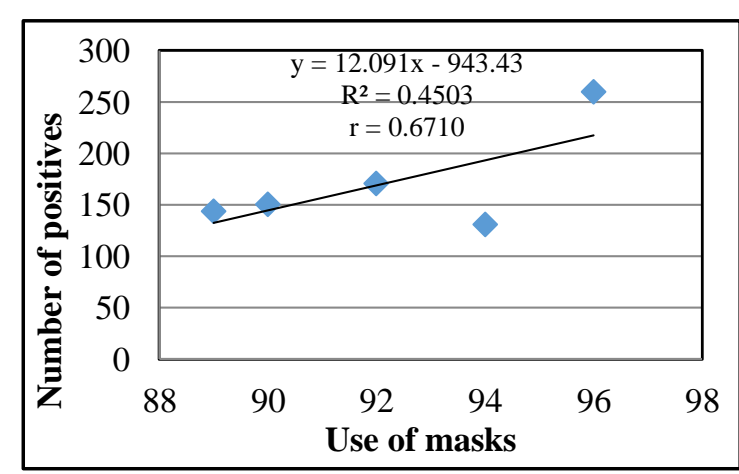

Figure 4: Correlation of use of masks with the number of infected by Covid-19 


\section{Journal of Global Education Sciences}

Vol. 3, $\mathrm{N}^{\circ}$ 1, 2021
A publication of

CINCADER

Centre of Research and Training for

Regional Development

Online at www.journals.cincader.org

Copyright (C) 2021, CINCADER.

ISSN 2663-3787

DOI: https://doi.org/10.32829/ges.v3i1.215

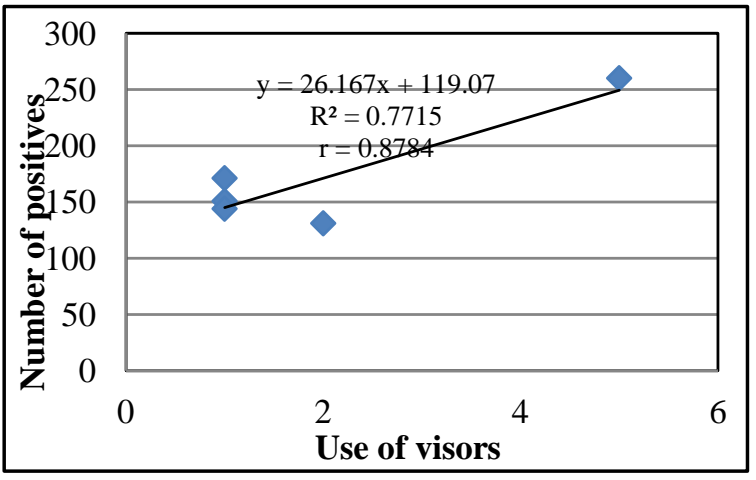

Figure 5: Correlation of the use of visors with the number of infected by Covid-19

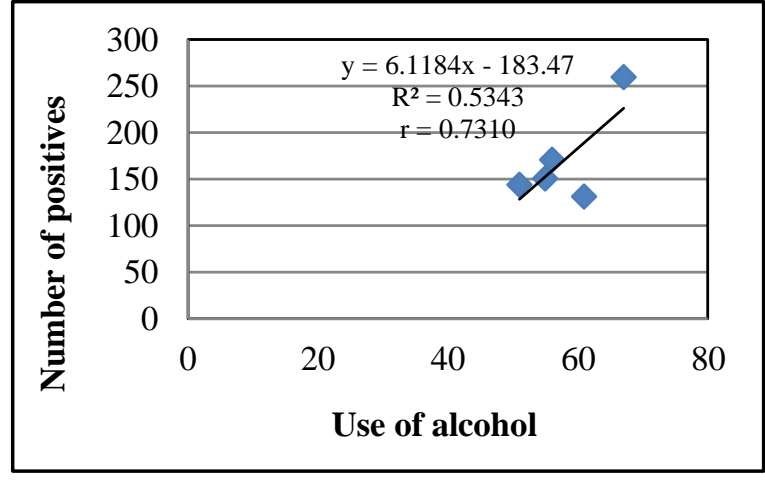

Figure 6: Correlation of alcohol use with the number of infected by Covid-19

Analysis of variance of the protection measures in relation to the number of infected

Regarding the results of the analysis of variance at $5 \%$ error, it was determined that there was no effect of the protection measures in relation to the infected; With the exception of the use of visors, where it can be observed that it influences very slightly (See table 4).

Table 4: Analysis of variance of protection measures and those infected

\begin{tabular}{lccc}
\hline Biosafety standards & F Calculated & F tabulated & Interpretation to 5\% \\
\hline Distancing & 3.75974 & 10.13 & No influence \\
Use of Face mask & 2.45765 & 10.13 & No influence \\
Use of Visors & 10.1316 & 10.13 & Yes influence \\
Use of Alcohol & 3.4422 & 10.13 & No influence \\
\hline
\end{tabular}

Note: Tabulated $\mathrm{F}$ was obtained from degrees of freedom 1 and error 3 , data from Fisher's table at $95 \%$ which is equal to 10.13 .

\section{Conclusions}

- It was determined that at the end of the year there was a relaxation in the use of the established protection measures, which influenced the increase in infections and deaths from Covid-19, due to the end of the year holidays and labor informality.

- Concerning the correlation of protection measures with the number of infected, it is established that there is adequate prevention of Covid-19, maintaining distance, due to the use of alcohol and masks; However, the use of visors according to the statistical result, is not favorable to prevent contagions, but only slightly.

- Regarding the analysis of variance of the protection measures and the number of infected, it was determined that they had an efficient influence in reducing the spread of the virus: distancing, use of a mask, use of alcohol; However, the low use of visors had no effect on reducing the number of infections. 


\section{Journal of Global Education Sciences}

Vol. 3, $\mathbf{N}^{\circ}$ 1, 2021

\section{CINGADER}

Centre of Research and Training for

Regional Development

Online at www.journals.cincader.org

Copyright (c) 2021, CINCADER.

ISSN 2663-3787

DOI: https://doi.org/10.32829/ges.v3i1.215

\section{References}

Cabezas, C., 2020. Pandemia de la COVID-19: Tormentas y retos. Revista Peruana de Medicina

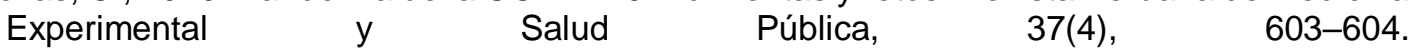
https://doi.org/10.17843/rpmesp.2020.374.6866

Dawood, A. A., \& Dawood, Z. A., 2021. How will the second wave of the dreadful COVID-19 be with the increasing number of the infected cases and mortality in Iraq? Vacunas. https://doi.org/10.1016/j.vacun.2020.09.007,

Instituto Nacional de Estadística e Informática (INEI). 2017. Compendio Estadístico Lima Provincias 2016. https://www.inei.gob.pe/media/MenuRecursivo/publicaciones_digitales/Est/Lib1521/Libro.p df,

Laguna, C., 2014. Correlación y regresión lineal. Diplomado en salud pública. Instituto Aragonés de Ciencias de la Salud. http://www.ics-aragon.com/cursos/saludpublica/2014/pdf/M2T04.pdf,

Llerena L., R., \& Sánchez N., C., 2020. Emergencia, gestión, vulnerabilidad y respuestas frente al impacto de la pandemia COVID-19 en el Perú. SciELO, 1-16. https://doi.org/https://doi.org/10.1590/SciELOPreprints.94,

López, L., \& Rodó, X., 2020. The end of social confinement and COVID-19 re-emergence risk. Nature Human Behaviour, 4(7), 746-755. https://doi.org/10.1038/s41562-020-0908-8,

Mendoza Murillo, P., \& Mendoza Murillo, D., 2020. Riesgo de transmisión y bioseguridad del SARS-COV-2 por aerosoles generados durante los procedimientos odontológicos. Cátedra Villarreal, 8(1). https://doi.org/10.24039/cv202081764,

Ministry of Health, 2017. DataSet de Fallecidos por COVID-19. Plataforma Nacional de Datos Abiertos. https://www.datosabiertos.gob.pe/dataset/fallecidos-por-covid-19-ministerio-desalud-minsa/resource/4b7636f3-5f0c-4404-8526,

Sedano-Chiroque, F. L., Rojas-Miliano, C., \& Vela-Ruiz, J. M., 2020. Perspective on the Primary Prevention of COVID-19. Revista de La Facultad de Medicina Humana, 20(3), 490-497. https://doi.org/10.25176/RFMH.v20i3.3031,

Serra, M. Á., 2020. COVID-19. De la patogenia a la elevada mortalidad en el adulto mayor y con comorbilidades. Revista Habanera de Ciencias Médicas, 19(3), 1-12. http://scielo.sld.cu/pdf/rhcm/v19n3/1729-519X-rhcm-19-03-e3379.pdf. 